\title{
A preliminary study of the effect of pregnancy and of lactation on the voluntary intake of food by cows
}

\author{
BY R. C. CAMPLING* \\ National Institute for Research in Dairying, Shinfield, Reading \\ (Received 12 March 1965-Accepted 27 September 1965)
}

\begin{abstract}
1. Monozygotic twin cattle were used in a preliminary study of the effect of pregnancy and of lactation on the voluntary intake of food and water, and on eating and ruminating behaviour. Also, results are reported of an experiment with five pairs of monozygotic twin heifers to examine the variation within pairs of twins in voluntary intake of food and water and eating and ruminating behaviour. 2. Voluntary food and water intakes were measured during the last few weeks of pregnancy and during early lactation. Within each twin pair one twin was pregnant or lactating and the other non-lactating and not pregnant, and the food and water intakes of a pair of twins were measured simultaneously. 3. On average the variation in voluntary intake of hay within pairs of non-pregnant, monozygotic twin heifers was $0.2 \mathrm{~kg}$ or $3 \%$ of the mean daily hay intake. 4 . The effect of pregnancy was observed in six pairs of twins and in five of the pairs the pregnant animal ate less hay than its non-pregnant twinmate; in four of these five pairs the effect was small (13\%). Changes in eating and ruminating behaviour associated with pregnancy were small; the pregnant animals ate concentrates and hay more slowly and ruminated longer than the non-pregnant animals. 5. Lactation was associated with a mean increase of $29 \%$ in hay intake in eight out of the nine pairs studied. In four pairs of twins given a diet of concentrates alone the lactating animal ate on average $8 \%$ more than the non-lactating animal. The lactating cows tended to eat concentrates and hay more quickly than the non-lactating cows; because of differences in the ratio of hay to concentrates it was not possible to interpret the changes in rumination that occurred with lactation.
\end{abstract}

Few observations have been made of the effect of pregnancy and of lactation on the voluntary intake of food by dairy cattle. Hesselbarth (1954) and Mäkelä (1956) observed a decline in voluntary food intake in cows in late pregnancy. However, Broster, Tuck \& Balch (1964) found no indication of a reduction in food intake by heifers in late pregnancy, and Hutton (1963) remarked that his limited information suggested that differences in voluntary food intake between pregnant and nonpregnant cows were small.

The effect of lactation on voluntary food intake was studied by Hutton ( 1963 ) using monozygotic twin cattle offered freshly cut herbage. He reported that the lactating twin ate, on average, $47 \%$ more food than its non-lactating twin. Estimates of the food intake of grazing cows using the chromic oxide technique suggested that lactating cows ate $28 \%$ more food than unrelated non-lactating cows grazing the same pasture (Elliott, Fokkema \& French, 196r). There are several reports of the changes in voluntary intake of food by stall-fed cows during the course of lactation (e.g. Graves, Dawson, Kopland, Watt \& Van Horn, 1938; Legates, Murley \& Waugh, 1956; Trimberger, Gray, Johnson, Wright, Vanvleck \& Henderson, I963), but in none of these studies was a group of comparable non-lactating cows kept under similar conditions and offered the same food ad lib. Also, in at least one of these reports (Trimberger et al. 1963) the method of giving grain according to milk yield

* Present address: Wye College, Nr Ashford, Kent. 
could have affected the voluntary intake of hay. Therefore it was decided to make a preliminary study of the voluntary intake of food by monozygotic twin dairy cattle offered conserved foods during late pregnancy and early lactation. Monozygotic twin cattle were used because they offer a convenient way of making simultaneous comparisons between the pregnant or lactating animal and the non-lactating, non-pregnant animal. The uniformity of grazing behaviour and of many other characteristics of monozygotic twin cattle is well known from the work of Hancock (1950, 1952). Since similar observations of voluntary food intake and the eating and ruminating behaviour of stall-fed animals given conserved roughages were not available an experiment was first conducted to examine the uniformity of voluntary food intake and the eating and ruminating behaviour of monozygotic twin cattle.

\section{EXPERIMENTAL}

Expt I. Five pairs of non-pregnant monozygotic twin heifers aged between $\mathrm{I} 2$ and I8 months were used to study the uniformity of voluntary intake of food and water, and of eating and ruminating behaviour. Each animal was given $4.5 \mathrm{~kg}$ hay daily and, after 14 days, recordings of eating and ruminating behaviour were made on 3 consecutive days. During a further I 4 days, hay was offered ad lib. Over the last ro days of this period the voluntary intakes of hay and water were measured and, on 3 days, observations were made of the eating and ruminating behaviour of each animal.

Expt 2. Six pairs of non-lactating monozygotic twin cattle, of which one member of each pair was pregnant, were used to study the effect of pregnancy on the voluntary intake of food and water during the last few weeks of pregnancy. Observations were made on 3 days of the eating and ruminating behaviour of four of the pairs of twins. Each twin pair received daily the same constant amount of concentrates, and hay was offered ad lib. A few days before parturition, the pregnant animals were moved to a box and kept unrestrained until after parturition; the intakes of food and water were not measured during this time.

Expt 3. Eleven pairs of monozygotic twin cattle were used to study the effect of lactation on voluntary food and water intake and on eating and ruminating behaviour. Within each twin pair only one cow was lactating; its twin was not pregnant and none of the cows was mated during the experiment. Six of the eleven pairs were those used in the first part of the investigation to study the effect of pregnancy. The cows were milked by machine twice daily throughout the experiment.

With nine pairs of twins (nos. 8, 9, 10, I1, 12, 13, 14, 15 and 16) each member of a twin pair received daily the same constant amount of concentrates, and hay was offered ad lib. A record was kept of the food intake and the amount of water drunk daily by each animal, and recordings were made of the eating and ruminating behaviour of eight of the pairs of twins during a period of 3 days. Two other pairs of twins (nos. 6 and 7) were given a diet of concentrates alone shortly after calving and measurements were made of the voluntary food and water intake of each cow; recordings of eating and ruminating behaviour were not made with this diet. Twin pairs nos. I 2 and 16 were changed to the all-concentrate diet after 7 weeks on the diet of 
restricted concentrates and hay ad lib. With these two pairs (nos. 12 and 16 ) the voluntary intakes of concentrates and water were measured daily over a period of 6 weeks.

Animals and housing. In the three experiments a total of sixteen pairs of monozygotic twin cattle were used. A description of the breed and age of the five pairs of heifers used in Expt $\mathbf{I}$ is given in Table I. Similar information for the twins used in Expts 2 and 3 is given in Table 2 together with the dates of calving during Expt 3 and the number of lactations of each animal before the experiment. The methods of collection, rearing and diagnosis of monozygosity of cattle twins at this Institute were described by Foot, Dodd \& Soffe (I960). The twins used in the study of pregnancy and lactation were from one of the Institute's dairy herds and consisted of pairs of twins in which delays in breeding had made it difficult to make simultaneous comparisons of lactation within pairs. It seems unlikely that any association existed between the poor reproductive performance and food intake of the twins, but if there was the comparisons made in Expts 2 and 3 would not be valid.

Table I. Expt $\mathrm{I}$. Breed and age of the heifers

$\begin{array}{clcc}\begin{array}{c}\text { Pair } \\ \text { no. }\end{array} & \text { Breed } & \overbrace{\text { Years }}^{\text {Age at start of }} \begin{array}{c}\text { Months } \\ \text { experiment }\end{array} \\ \text { I } & \text { Shorthorn } & \text { I } & 8 \\ 2 & \text { Friesian } & \text { I } & 7 \\ 3 & \text { Friesian } & \text { I } & 5 \\ 4 & \text { Friesian } & \text { I } & \text { I } \\ 5 & \text { Friesian } & \text { I } & 0\end{array}$

Table 2. Expts 2 and 3. Breed of cow, age at calving, date of calving and number of lactations before the experiments

\begin{tabular}{|c|c|c|c|c|c|}
\hline \multirow[b]{2}{*}{ Pair no. } & \multirow[b]{2}{*}{ Breed } & \multicolumn{2}{|c|}{ Age at calving } & \multirow{2}{*}{$\begin{array}{l}\text { Date of calving } \\
\text { during the } \\
\text { experiments }\end{array}$} & \multirow{2}{*}{$\begin{array}{c}\text { No. of } \\
\text { lactations }\end{array}$} \\
\hline & & Years & Months & & \\
\hline 6 & Shorthorn & I0 & 4 & 9. i. 62 & 4 \\
\hline 7 & Friesian & 7 & $\circ$ & 31. i. 62 & 3 \\
\hline 8 & Friesian $\times$ Shorthorn & 7 & 7 & 9. v. 62 & 4 \\
\hline 9 & Shorthorn & 5 & 5 & 2. v. 62 & 2 \\
\hline I0 & Friesian & 5 & 7 & 29. v. 62 & 2 \\
\hline II & Ayrshire & 6 & $\circ$ & I3. xii. 62 & 3 \\
\hline $\mathrm{x}_{2}$ & Friesian $\times$ Ayrshire & 6 & 2 & I7. ii. 62 & 3 \\
\hline $\mathrm{I}_{3}$ & Friesian & 2 & 8 & $21 . \mathrm{ix} .63$ & 0 \\
\hline$x_{4}$ & Shorthorn & 3 & I0 & 7. ix. 63 & I \\
\hline 15 & Friesian $\times$ Shorthorn & 4 & 9 & I1. xi. 63 & 2 \\
\hline 16 & Ayrshire & 5 & o & 6. ii. 64 & 2 \\
\hline
\end{tabular}

During the experiments the animals were kept in a metabolism house in standings which prevented food being stolen by neighbours. Water and salt licks containing trace minerals were accessible at all times.

Foods. The concentrates were in the form of pellets and composed of barley 17 , maize 20, wheat bran 20, decorticated groundnut meal 15, copra cake Io, palmkernel cake 5, molasses Io, dicalcium phosphate $\mathrm{I}$, calcium carbonate $\mathrm{I}$ and salt $\mathrm{I} \%$, 
with $5 \times 10^{6}$ i.u. vitamin $A$ and $I \times 10^{6}$ i.u. vitamin $D$ added per ton. The chemical composition of the concentrate is given in Table 3 . Several different batches of hay were used and the chemical composition of each is given in Table 3 together with details of the animals which received it.

Determination of voluntary intake of food. The daily allowance of food was given once daily at $10.00 \mathrm{~h}$ and the uneaten food removed and weighed at $09.50 \mathrm{~h}$ the next day. The amount offered was adjusted daily so that the uneaten food was about $15 \%$ of the amount offered. When a controlled amount of concentrates was offered this was given in one meal immediately before the hay, and when possible the animals were trained to eat the concentrates before hay was given. Each animal had access at all times to water from a cowshed drinking bowl. Each bowl was supplied with water from a tank filled daily, the amount drunk by the cows being shown by graduated glass indicator-tubes on the side of the tanks. The amount consumed was recorded daily.

Table 3. Chemical composition of the foods

\begin{tabular}{|c|c|c|c|c|c|c|c|}
\hline \multirow[b]{2}{*}{ Food } & \multirow{2}{*}{$\begin{array}{l}\text { Pair nos. } \\
\text { receiving food }\end{array}$} & \multirow{2}{*}{$\begin{array}{c}\text { Dry } \\
\text { matter } \\
(\%)\end{array}$} & $\begin{array}{l}\text { Crude } \\
\text { protein }\end{array}$ & $\begin{array}{l}\text { Ether } \\
\text { extract }\end{array}$ & $\begin{array}{l}\text { Crude } \\
\text { fibre }\end{array}$ & $\begin{array}{c}\text { Nitrogen- } \\
\text { free } \\
\text { extract }\end{array}$ & Ash \\
\hline & & & \multicolumn{5}{|c|}{ ( $\%$ of dry matter) } \\
\hline Hay A & 8 & $83 \cdot 8$ & $8 \cdot 6$ & $4^{\cdot 2}$ & $33 \cdot 2$ & $46 \cdot I$ & $7 \cdot 9$ \\
\hline Hay $\mathbf{B}$ & $\begin{array}{l}\mathrm{I}, 2,3,4,5,9, \text { IO, II } \\
\quad \mathrm{I} 2\end{array}$ & $83 \cdot 1$ & $8 \cdot 4$ & $I \cdot 4$ & $34 \div 3$ & $50 \cdot \mathrm{r}$ & $5 \cdot 8$ \\
\hline Hay C & I3, 14, I5, 16 & $82 \cdot 7$ & $9 \cdot 2$ & 0.8 & $36 \cdot 0$ & $45^{\cdot 8}$ & $8 \cdot 2$ \\
\hline Concentrates & $\begin{array}{l}6,7,8,9,10,11,12 \\
13,14,15,16\end{array}$ & $86 \cdot I$ & $18 \cdot 7$ & $I \cdot 6$ & $5 \cdot 9$ & $66 \cdot 6$ & $7 \cdot 2$ \\
\hline
\end{tabular}

Recording of eating and ruminating behaviour. The apparatus was that described by Freer, Campling \& Balch (1962) and Balch, Kelly \& Heim (1951) and consisted of a small, lightly inflated balloon placed under a side strap on a leather head-stall, and connected to a tambour in a recorder (Evershed \& Vignoles Ltd). The tambour operated a pen and provided a continuous record of jaw movements. The record was started immediately before a meal at $10.00 \mathrm{~h}$ and continued for $72 \mathrm{~h}$ using a chart speed of $0.5 \mathrm{in} / \mathrm{min}$. The records were analysed to determine the time the cows spent eating, ruminating or resting. Periods during which the cows were neither eating nor ruminating were regarded as 'rest' periods. It was assumed that any rumination observed was due to the hay as the diet of concentrates alone did not induce rumination in cows in another experiment (Freer \& Campling, 1965).

Measurement of body-weight. The cows were weighed on 3 consecutive days each week; during the winter of 1962 ice and snow prevented the weighing of the animals.

\section{RESULTS}

Expt I

Voluntary intake of hay and water. The mean daily voluntary intake of hay and the mean daily amount of water drunk by each animal, together with the mean bodyweights, are given in Table 4 . The mean voluntary intake of hay was $8.3 \mathrm{~kg}$ and the 
amount of water drunk $23.2 \mathrm{~kg}$. The voluntary intakes of hay by members of a twin pair were similar and the mean difference in intake of hay within pairs was only $0.22 \mathrm{~kg}$ or $2.6 \%$ of the mean intake. Between pairs of twins the mean voluntary intake of hay varied from 9.1 kg in pair no. 2 to $7.4 \mathrm{~kg}$ in pair no. 4. The amount of water drunk daily varied from a mean intake of $27.0 \mathrm{~kg}$ in twin pair no. 1 to $19.5 \mathrm{~kg}$ in twin pair no. 4. The mean difference in the amount of water drunk within pairs was $2 \cdot 2 \mathrm{~kg}$ or $9.5 \%$ of the mean amount. The mean body-weight of the heifers was $375 \mathrm{~kg}$; within each twin pair the difference in body-weight was slight except within twin pair no. $\mathrm{r}$, which differed by $\mathrm{I} 4 \mathrm{~kg}$.

Table 4. Expt 1. Voluntary hay and water intakes and body-weights of heifers receiving hay ad lib.

$\begin{array}{cccc}\begin{array}{c}\text { Meifer } \\ \text { no. }\end{array} & \begin{array}{c}\text { May daily } \\ (\mathrm{kg})\end{array} & \begin{array}{c}\text { Mean daily } \\ \text { water drunk } \\ (\mathrm{kg})\end{array} & \begin{array}{c}\text { Mean } \\ \text { body-weight } \\ (\mathrm{kg})\end{array} \\ \text { I A } & 8 \cdot 6 & 25 \cdot 4 & 395 \\ \text { I B } & 8 \cdot 7 & 28 \cdot 6 & 38 \text { I } \\ \text { 2A } & 9 \cdot 3 & 24 \cdot 9 & 42 \text { I } \\ \text { 2 B } & 8 \cdot 9 & 21 \cdot 3 & 420 \\ \text { 3 A } & 8 \cdot 4 & 24 \cdot 5 & 353 \\ \text { 3B } & 8 \cdot 1 & 21 \cdot 3 & 358 \\ \text { 4A } & 7 \cdot 3 & 19 \cdot 5 & 354 \\ \text { 4B } & 7 \cdot 4 & 19 \cdot 5 & 355 \\ \text { 5 A } & 8 \cdot 1 & 23 \cdot 1 & 350 \\ \text { 5 B } & 8 \cdot 3 & 24 \cdot 0 & 359 \\ \text { Mean } & 8 \cdot 3 & \mathbf{2 3} \cdot 2 & 375\end{array}$

Table 5. Expt. 1. Mean daily eating and ruminating behaviour of heifers receiving $4.5 \mathrm{~kg}$ hay daily

\begin{tabular}{|c|c|c|c|c|c|}
\hline \multirow[b]{2}{*}{$\begin{array}{c}\text { Heifer } \\
\text { no. }\end{array}$} & \multicolumn{3}{|c|}{ Mean time ( $\mathrm{min} / \mathrm{kg}$ hay) spent } & \multirow{2}{*}{$\begin{array}{l}\text { No. of } \\
\text { boluses } \\
\text { regurgitated/ } \\
\text { 100 min }\end{array}$} & \multirow{2}{*}{$\begin{array}{l}\text { No. of } \\
\text { periods of } \\
\text { rumination }\end{array}$} \\
\hline & Eating & Ruminating & $\begin{array}{l}\text { Eating }+ \\
\text { ruminating }\end{array}$ & & \\
\hline I A & $23 \cdot 1$ & $80 \cdot 2$ & $103 \cdot 3$ & 99 & 16 \\
\hline I B & $27 \cdot 6$ & $75 \cdot 6$ & $103 \cdot 2$ & 105 & 17 \\
\hline $2 \mathrm{~A}$ & $26 \cdot 9$ & $76 \cdot 2$ & $103 \cdot 1$ & 120 & 14 \\
\hline $2 B$ & $34 \cdot 2$ & $74 \cdot 4$ & $108 \cdot 6$ & Irg & 14 \\
\hline $3 \mathrm{~A}$ & $28 \cdot 4$ & $73 \cdot 3$ & $101 \cdot 7$ & I IO & 17 \\
\hline $3 \mathrm{~B}$ & $3 r \cdot 8$ & $69 \cdot 6$ & $\mathrm{IOI} \cdot 4$ & I 8 & I7 \\
\hline $4 B$ & $38 \cdot 7$ & $70 \cdot 0$ & $108 \cdot 7$ & IOI & 15 \\
\hline $4 B$ & $4 I \cdot 3$ & $62 \cdot 0$ & $103 \cdot 3$ & 109 & 14 \\
\hline $5 \mathrm{~A}$ & $3 \mathrm{I} \cdot 8$ & $63 \cdot 8$ & $95 \cdot 6$ & 114 & I 8 \\
\hline $5 \mathrm{~B}$ & $27^{\circ} \mathrm{I}$ & $65 \cdot 4$ & $92 \cdot 5$ & 110 & 19 \\
\hline Mean & $3 I \cdot I$ & $7 I \cdot 1$ & $102 \cdot 2$ & IIO & 16 \\
\hline
\end{tabular}

Eating and ruminating behaviour. The behaviour of the heifers was expressed as min spent eating and ruminating per $\mathrm{kg}$ hay eaten, as was done by Freer et al. (1962). The results given in Table 5 describe the eating and ruminating behaviour of the heifers given daily $4.5 \mathrm{~kg}$ hay, and the results in Table 6 were obtained when the heifers were 
offered hay ad lib. Given $4 \cdot 5 \mathrm{~kg}$ hay daily the mean time spent eating was $3 \mathrm{r} \cdot \mathrm{I} \mathrm{min} /$ $\mathrm{kg}$ hay and ruminating $7 \mathrm{I}^{\circ} \cdot \mathrm{r} \mathrm{min} / \mathrm{kg}$. The mean time spent chewing per kg hay was thus I02.2 min (Table 5 ). Although the mean time spent eating and ruminating by each pair of twins varied, there was a similarity in the eating and ruminating behaviour of members of a twin pair. The largest differences within the pairs of twins in the time spent chewing during eating and ruminating were 5.6 and $5.5 \mathrm{~min} / \mathrm{kg}$ hay in twin pairs nos. 2 and 4 respectively; these differences were about $5 \%$ of the mean time spent chewing per kg hay by the the five pairs of twins (Table 5). During rumination the mean number of boluses regurgitated per $100 \mathrm{~min}$ varied from 102 (twin pair no. I) to Irg (pair no. 2) and, on average, the difference within pairs was only 5. The average daily number of periods of rumination was similar within pairs of twins and varied between pairs from 14 in pair no. 2 to 18 in pair no. 5 .

Table 6. Expt I. Mean daily eating and ruminating behaviour

\begin{tabular}{|c|c|c|c|c|c|c|c|}
\hline \multirow{3}{*}{$\begin{array}{c}\text { Heifer } \\
\text { no. }\end{array}$} & \multirow{3}{*}{$\begin{array}{c}\text { Mean } \\
\text { hay } \\
\text { intake } \\
\text { on } \\
\text { recording } \\
\text { days } \\
\text { (kg) }\end{array}$} & \multicolumn{3}{|c|}{ Mean time (min $/ \mathrm{kg}$ hay) spent } & \multirow{3}{*}{$\begin{array}{l}\text { No. of } \\
\text { boluses } \\
\text { regurgitated/ } \\
\text { roo min }\end{array}$} & \multirow{2}{*}{\multicolumn{2}{|c|}{ No. of periods of }} \\
\hline & & & & Eating + & & & \\
\hline & & Eating & Ruminating & ruminating & & Eating & Ruminating \\
\hline $\begin{array}{l}\text { I A } \\
\text { r B }\end{array}$ & $8 \cdot 3$ & $5 \mathrm{I} \cdot \mathrm{I}$ & $62 \cdot 8$ & II 3.9 & 100 & 7 & I3 \\
\hline I B & $8 \cdot 5$ & 554 & $63 \cdot 9$ & II $9 \cdot 3$ & 94 & I I & 15 \\
\hline $\begin{array}{l}2 \mathrm{~A} \\
2 \mathrm{~B}\end{array}$ & $\begin{array}{l}9 \cdot 6 \\
9 \cdot 1\end{array}$ & $\begin{array}{r}53 \cdot 9 \\
44 \cdot 8\end{array}$ & $\begin{array}{l}60 \cdot 6 \\
6 r \cdot 0\end{array}$ & $\begin{array}{l}\text { Y14.5 } \\
105.8\end{array}$ & $\begin{array}{r}99 \\
\text { IOI }\end{array}$ & $\begin{array}{l}\text { I0 } \\
\text { I0 }\end{array}$ & $\begin{array}{l}\text { I3 } \\
\text { I5 }\end{array}$ \\
\hline $\begin{array}{l}3 \mathrm{~A} \\
\mathbf{3}_{\mathrm{B}}\end{array}$ & $\begin{array}{l}8 \cdot 5 \\
8 \cdot 4\end{array}$ & $\begin{array}{l}48 \cdot 4 \\
49 \cdot 6\end{array}$ & $\begin{array}{l}54 \cdot 9 \\
62 \cdot 0\end{array}$ & $\begin{array}{l}103.3 \\
11 \mathrm{II} .6\end{array}$ & $\begin{array}{l}103 \\
111\end{array}$ & $\begin{array}{l}\mathrm{I} 2 \\
\mathrm{II}\end{array}$ & $\begin{array}{l}\mathrm{I} 6 \\
\mathrm{I} 6\end{array}$ \\
\hline $\begin{array}{l}4 \mathrm{~A} \\
4 \mathrm{~B}\end{array}$ & $\begin{array}{l}7 \cdot 4 \\
7 \cdot 1\end{array}$ & $\begin{array}{l}69 \cdot 9 \\
75 \cdot 7\end{array}$ & $\begin{array}{l}50 \cdot 6 \\
62 \cdot 4\end{array}$ & $\begin{array}{l}120 \cdot 5 \\
138 \cdot 1\end{array}$ & $\begin{array}{r}95 \\
100\end{array}$ & $\begin{array}{l}14 \\
13\end{array}$ & $\begin{array}{l}\text { I3 } \\
\text { I5 }\end{array}$ \\
\hline $\begin{array}{l}5 \mathrm{~A} \\
5 \mathrm{~B}\end{array}$ & $\begin{array}{l}8 \cdot 3 \\
8 \cdot 4\end{array}$ & $\begin{array}{l}52 \cdot 0 \\
45 \cdot 2\end{array}$ & $\begin{array}{l}55^{\circ} 2 \\
55^{\circ} 0\end{array}$ & $\begin{array}{l}107.2 \\
100.2\end{array}$ & $\begin{array}{r}104 \\
98\end{array}$ & $\begin{array}{l}\text { II } \\
\text { II }\end{array}$ & $\begin{array}{l}18 \\
18\end{array}$ \\
\hline Mean & $8 \cdot 4$ & $54 \cdot 6$ & $58 \cdot 8$ & II $3 \cdot 4$ & 100 & II & 15 \\
\hline
\end{tabular}

When offered hay ad lib. heifers spent, on average, $54.6 \mathrm{~min} / \mathrm{kg}$ hay eating and $58.8 \mathrm{~min} / \mathrm{kg}$ ruminating, and the total time spent chewing per $\mathrm{kg}$ hay was $113.4 \mathrm{~min}$ (Table 6). The differences in the time spent eating and ruminating within pairs of twins were greater than those observed when the heifers were given daily $4.5 \mathrm{~kg}$ hay; for example, the mean difference in the time spent chewing per kg hay was 9.4 min or $8.3 \%$ of the mean time for all the animals. Within pairs the mean difference in the number of boluses regurgitated per 100 min was 5 or $5 \%$. With the exception of pair no. I, the animals of each pair of twins spent a similar number of periods eating each day. The average daily number of periods of rumination also tended to be an individual characteristic of each pair of twins. Twin pairs nos. I and 2 each spent fourteen periods ruminating and pair no. 5 eighteen periods; these values differed little from those found when the twins received $4.5 \mathrm{~kg}$ hay each day. 


\section{Expt 2}

Voluntary intake of hay and water. The time at which measurements of voluntary intake of food and water were made, the duration of the measurements, the mean daily food intake, the amount of water drunk and the mean body-weights are given in Table 7. With the exception of pair no. II the test periods were of several weeks' duration. In five of the six pairs the pregnant animals ate less hay than their nonpregnant twins, although with one of these pairs (no. 14) it seems unlikely that there was any real difference between the voluntary hay intakes of the pregnant and non-pregant twins. There was no evidence of any effect of pregnancy on the amount of water drunk in five of the six pairs. With pair no. 12 the pregnant animal drank daily, on average, $12.3 \mathrm{~kg}$ less water than its twin; also, the pregnant cow ate considerably less food than its sister. The mean difference in body-weight within four pairs of twins was $65 \mathrm{~kg}$ and probably reflected the weight of the gravid uterus.

Table 7. Expt 2. Effect of pregnancy on voluntary food intake, the amount of water drunk and the mean body-weight of the cows shortly before calving

\begin{tabular}{|c|c|c|c|c|c|c|}
\hline \multirow[b]{3}{*}{ Cow no.* } & \multicolumn{2}{|c|}{ Test period } & \multirow{2}{*}{\multicolumn{2}{|c|}{$\begin{array}{l}\text { Mean daily food } \\
\text { intake }(\mathrm{kg})\end{array}$}} & \multirow{3}{*}{$\begin{array}{c}\text { Mean } \\
\text { daily } \\
\text { water } \\
\text { drunk } \\
(\mathrm{kg})\end{array}$} & \multirow{3}{*}{$\begin{array}{c}\text { Mean } \\
\text { body- } \\
\text { weight } \\
\text { (kg) }\end{array}$} \\
\hline & \multirow{2}{*}{$\begin{array}{c}\text { Began } \\
\text { (days } \\
\text { pre- } \\
\text { partum) }\end{array}$} & \multirow{2}{*}{$\begin{array}{c}\text { Dura- } \\
\text { tion } \\
\text { (days) }\end{array}$} & & & & \\
\hline & & & $\begin{array}{l}\text { Concen- } \\
\text { trates }\end{array}$ & Hay & & \\
\hline $\begin{array}{l}\text { I I } P \\
\text { I I C }\end{array}$ & $2 I$ & $\begin{array}{l}\text { I I } \\
\text { I I }\end{array}$ & $\begin{array}{l}7.0 \\
7.0\end{array}$ & $\begin{array}{l}5 \cdot 9 \\
6 \cdot 7\end{array}$ & $\begin{array}{l}4 I \cdot 2 \\
40 \cdot 8\end{array}$ & - \\
\hline $\begin{array}{l}12 \mathrm{P} \\
12 \mathrm{C}\end{array}$ & 32 & $\begin{array}{l}21 \\
21\end{array}$ & $\begin{array}{l}7 \cdot 0 \\
7 \cdot 0\end{array}$ & $\begin{array}{r}6 \cdot 5 \\
I I \cdot I\end{array}$ & $\begin{array}{l}41 \cdot 7 \\
54 \cdot 0\end{array}$ & - \\
\hline $\begin{array}{l}1_{3} P \\
1_{3} \mathrm{C}\end{array}$ & 53 & $\begin{array}{l}49 \\
49\end{array}$ & $\begin{array}{l}5.0 \\
5.0\end{array}$ & $\begin{array}{l}5 \cdot 0 \\
6 \cdot 5\end{array}$ & $\begin{array}{l}26 \cdot 4 \\
28 \cdot 0\end{array}$ & $\begin{array}{l}647 \\
596\end{array}$ \\
\hline $\begin{array}{l}14 \mathrm{P} \\
14 \mathrm{C}\end{array}$ & 37 & $\begin{array}{l}35 \\
35\end{array}$ & $\begin{array}{l}6 \cdot 0 \\
6 \cdot 0\end{array}$ & $\begin{array}{l}6 \cdot 5 \\
6 \cdot 6\end{array}$ & $\begin{array}{l}38 \cdot 5 \\
37 \cdot 0\end{array}$ & $\begin{array}{l}56 r \\
494\end{array}$ \\
\hline $\begin{array}{l}\text { I }_{5} \mathrm{P} \\
\text { I }_{5} \mathrm{C}\end{array}$ & 45 & $\begin{array}{l}42 \\
42\end{array}$ & $\begin{array}{l}6 \cdot 0 \\
6 \cdot 0\end{array}$ & $\begin{array}{l}6 \cdot 6 \\
6 \cdot 4\end{array}$ & $\begin{array}{l}32 \cdot 4 \\
30 \cdot 6\end{array}$ & $\begin{array}{l}650 \\
586\end{array}$ \\
\hline $\begin{array}{l}16 \mathrm{P} \\
16 \mathrm{C}\end{array}$ & $4 \mathrm{I}$ & $\begin{array}{l}35 \\
35\end{array}$ & $\begin{array}{l}6 \cdot 0 \\
6 \cdot 0\end{array}$ & $\begin{array}{l}6 \cdot 5 \\
7 \cdot 8\end{array}$ & $\begin{array}{l}45 \cdot 7 \\
46 \cdot 1\end{array}$ & $\begin{array}{l}539 \\
460\end{array}$ \\
\hline \multicolumn{7}{|l|}{ Mean: } \\
\hline Pregnant cows & 38 & 32 & $\begin{array}{l}6 \cdot 2 \\
6 \cdot 2\end{array}$ & 6.2 & $37 \cdot 6$ & $599 \dagger$ \\
\hline Control cows & & 32 & $6 \cdot 2$ & $7 \cdot 5$ & $39^{\circ} 4$ & $534 \uparrow$ \\
\hline
\end{tabular}

Eating and ruminating behaviour. The time of recording, the mean intake of food on recording days, and the eating and ruminating behaviour are given in Table 8 . In each of the four pairs observed the pregnant cow ate concentrates more slowly and spent longer both eating and ruminating per kg hay than the non-pregnant animal, although the differences were very small in pair no. 16. Differences within pairs in the number of boluses regurgitated per roo min were also very small and there was no consistent difference associated with pregnancy. With the exception of twin pair 


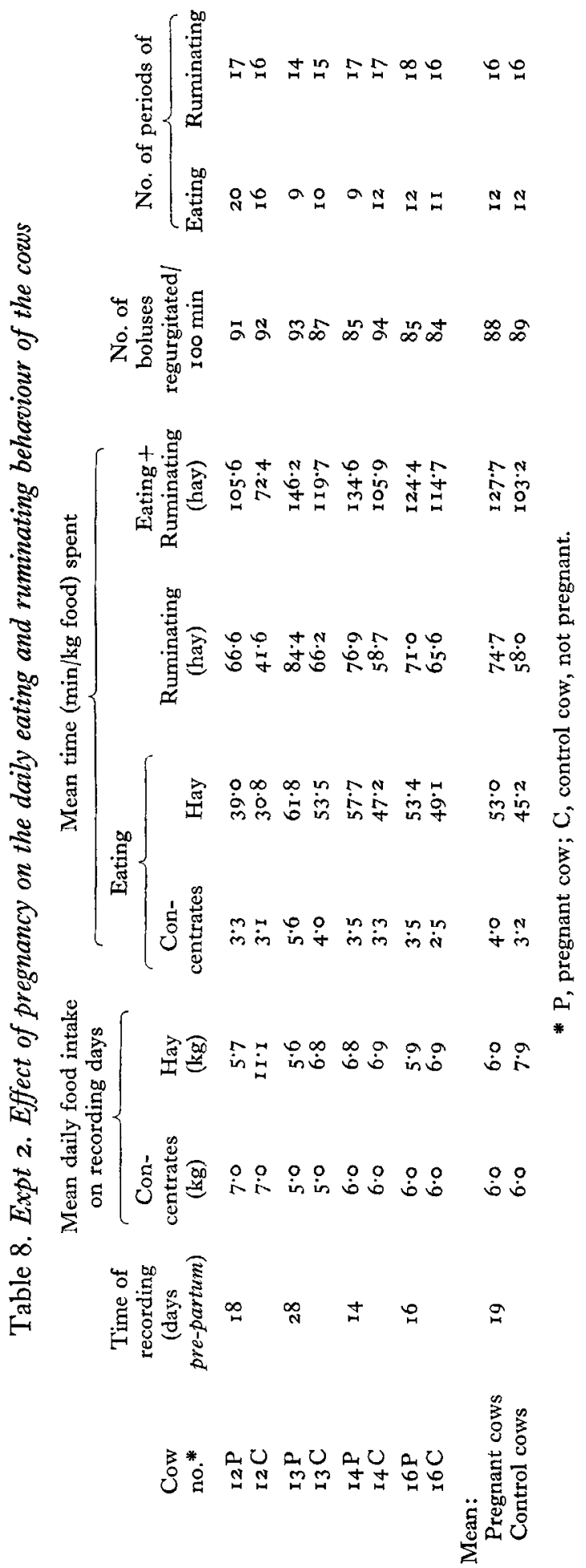

(2) 
no. I2, pregnancy was not associated with any marked change in the daily number of periods of eating and ruminating. With pair no. 12 the pregnant animal ate more frequently than the non-pregnant twin.

Table 9. Expt 3. Effect of lactation on the voluntary food intake and the water drunk by the cows, the mean milk yield and body-weight of the cows at the beginning and end of the test period ( $k g)$

\begin{tabular}{|c|c|c|c|c|c|c|c|}
\hline & Test & eriod & Mea & & & & \\
\hline & $\begin{array}{l}\text { Began } \\
\text { (days }\end{array}$ & Dura- & Concen- & & & $\begin{array}{l}\text { daily } \\
\text { milk }\end{array}$ & $\begin{array}{c}\text { Mean body-weight } \\
\text { (kg) }\end{array}$ \\
\hline Cow no.* & $\begin{array}{c}\text { post } \\
\text { partum) }\end{array}$ & $\begin{array}{l}\text { tion } \\
\text { (days) }\end{array}$ & $\begin{array}{c}\text { trates } \\
(\mathrm{kg})\end{array}$ & $\begin{array}{r}\text { Hay } \\
(\mathrm{kg})\end{array}$ & $\begin{array}{c}\text { drunk } \\
(\mathrm{kg})\end{array}$ & $\begin{array}{c}\text { yield } \\
(\mathrm{kg})\end{array}$ & Initial \\
\hline
\end{tabular}

Diet: restricted amount of concentrates and hay $a d$ lib.

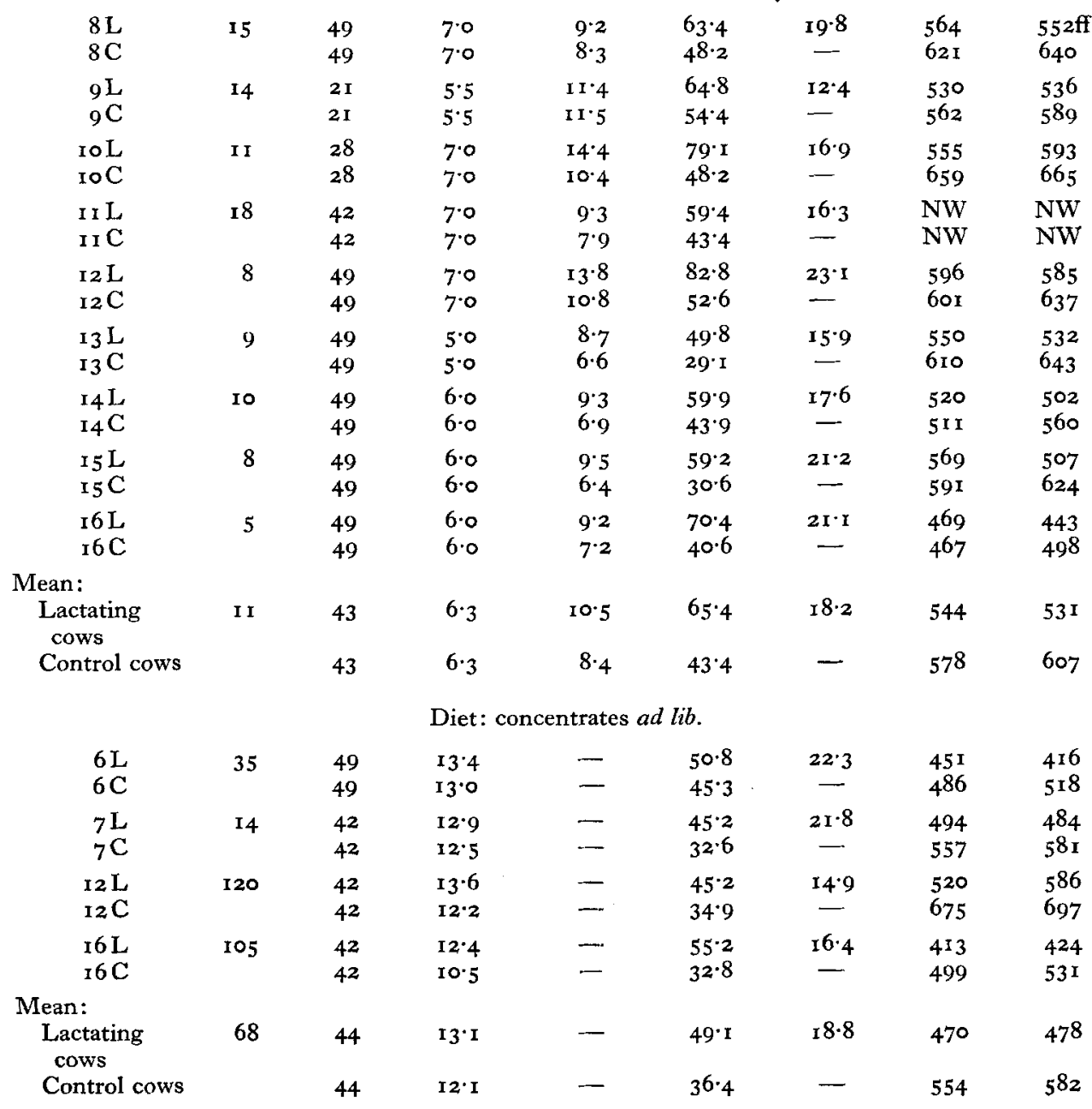

NW, not weighed

* L, lactating cow; C, control cow, not lactating. 


\section{Expt 3}

Voluntary intake of food and water. The results reported in Table 9 are the time and duration of the periods of measurement of food and water intake, the mean daily milk yield and body-weight of the animals at the beginning and end of the test period.

When offered hay ad lib. the lactating animals of eight of the nine pairs of twins ate, on average, $2.4 \mathrm{~kg}$ or $29 \%$ more hay than their non-lactating twin-mates. The difference in voluntary intake of hay associated with lactation varied from $48 \%$ or $3 . \mathrm{I} \mathrm{kg}$ in pair no. $\mathrm{I}_{5}$ to $\mathrm{II} \%$ or $0.9 \mathrm{~kg}$ in pair no. 8 . A mean difference of only $0 . \mathrm{I} \mathrm{kg}$ hay was found in pair no. 9, the non-lactating animal eating most hay. There was no close direct relationship between the mean daily milk yield, which ranged from $23^{\circ} \mathrm{I} \mathrm{kg}$ in twin no. $12 \mathrm{~L}$ to $12.4 \mathrm{~kg}$ in twin no. $9 \mathrm{~L}$, and the extent of differences in hay intake within pairs of twins.

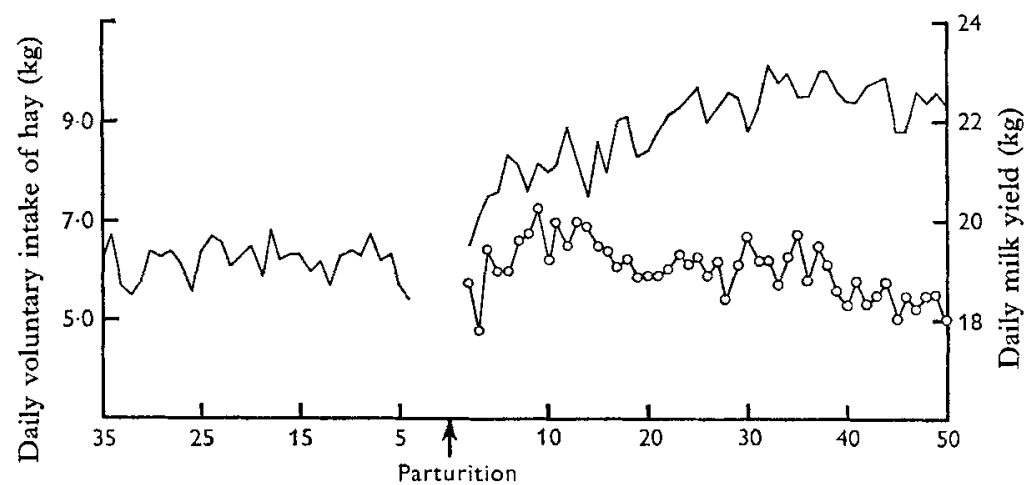

Days pre-partum

Days past partum

Fig. I. Expts 2 and 3. Mean daily voluntary intake of hay $(-)$ and milk yield $(\mathrm{O}-\mathrm{O})$ by four cows (nos. $1_{3} \mathrm{~L}, 1_{4} \mathrm{~L}, \mathrm{I}_{5} \mathrm{~L}$ and $16 \mathrm{~L}$ ) in late pregnancy and early lactation. Details of the diet are given on pp. $26-8$.

In four of the twins (nos. ${ }_{3} \mathrm{~L}, \mathrm{I}_{4} \mathrm{~L}, \mathrm{I}_{5} \mathrm{~L}$ and $\mathrm{I}_{6} \mathrm{~L}$ ) it was possible to observe the daily changes in voluntary intake of hay during the period $35^{-4}$ days pre-partum and between days $4-50$ post partum; throughout these periods the cows received a constant daily allowance of concentrates and hay ad lib. The mean results for the four cows are given graphically in Fig. 1 , and show that there was a very rapid increase in voluntary intake of hay immediately after parturition continuing until about day 25 post partum. After day 25 post partum hay intake remained about the same from day to day at $9.5 \mathrm{~kg}$ until the end of the test period at day 50 post partum. The mean daily milk production of the four cows rapidly reached a maximum of $20 \mathrm{~kg}$ about day ro and declined slowly to $18.5 \mathrm{~kg}$ on day 50 post partum.

The daily voluntary intake of hay by the non-lactating, non-pregnant cows remained steady throughout the experiments, and considerable increases occurred in their body-weights (see Table 9).

Given a diet of concentrates alone over periods of 6 or 7 weeks, differences in voluntary food intake within pairs were much smaller than the differences observed 
Vol. 20

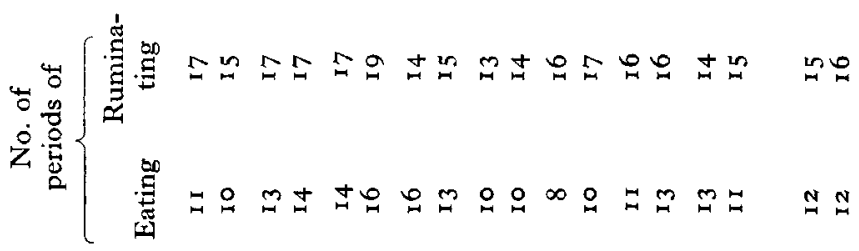

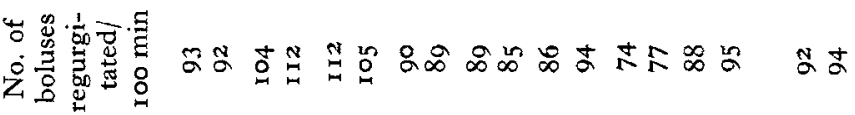

胥

$\frac{1}{2}$

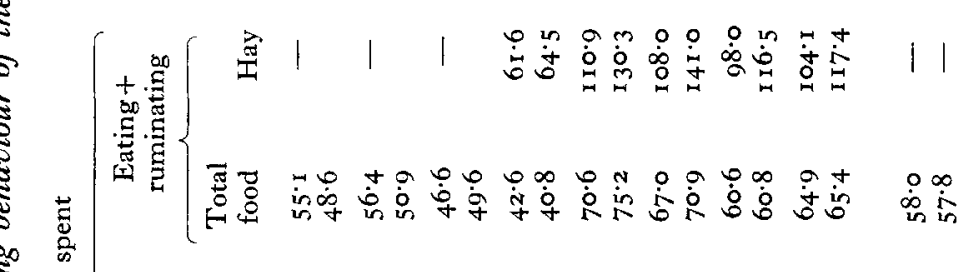

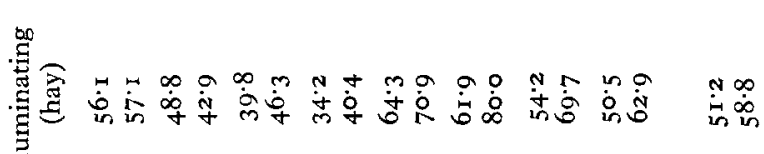

害泀

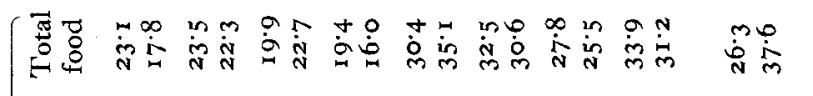

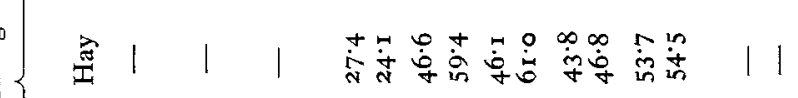

它

ì

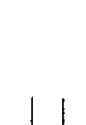

จ

芯

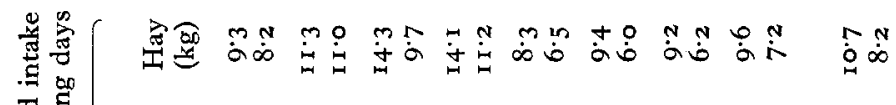

究

$\dot{9}$

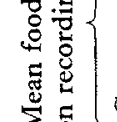

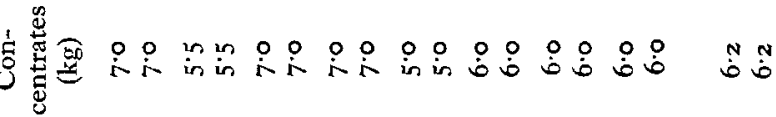

$\frac{\pi}{\frac{\pi}{\pi}}$

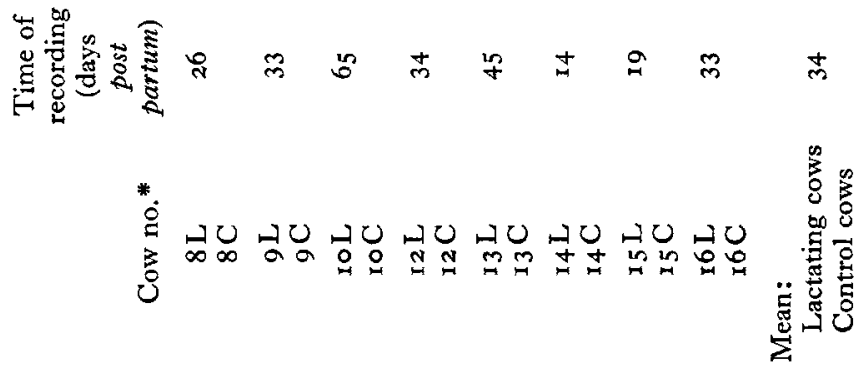


when hay was offered. In each of the four pairs which received the diet of concentrates ad lib. the lactating cow ate more than the non-lactating cow, but the differences were $1.9 \mathrm{~kg}$ or $17 \%$ in pair no. $16, \mathrm{I} \cdot 4 \mathrm{~kg}$ or $1 \mathrm{I} \%$ in pair no. 12 and $0.4 \mathrm{~kg}$ or $3.1 \%$ in pairs nos. 6 and 7. The mean daily milk yield was $18.8 \mathrm{~kg}$ and the content of fat in the milk was about $2 \cdot 1 \%$ during the period when the cows were given only concentrates.

Given hay $a d$ lib. the mean amount of water drunk daily by the lactating cows was $65.4 \mathrm{~kg}$ and by the non-lactating cows $43.4 \mathrm{~kg}$; the difference in water intake exceeded the mean daily milk yield of $18.4 \mathrm{~kg}$ by $4.6 \mathrm{~kg}$. With the diet of concentrates ad lib. the lactating cows again drank more water than their non-lactating twins, but the mean daily difference of $12.7 \mathrm{~kg}$ was less than the mean daily milk yield. The mean ratios of total water intake to dry matter consumed when hay was offered ad lib. were $4.9: 1$ in the lactating cows and 3.7:1 in the non-lactating cows; with the diet of concentrates the ratios were $4 \cdot 5: 1$ and $3 \cdot 6:$ : respectively.

Eating and ruminating behaviour. The time of recording, the intake of food and the behaviour of the cows are given in Table Io. In four of the five pairs of twins in which the time taken to eat concentrates was recorded, the lactating cows ate concentrates faster than the non-lactating cows; in the fifth pair (no. 3) there was no difference between the cows in rate of eating concentrates. Differences associated with lactation in rate of eating hay were small except in twin pairs nos. $I_{3}$ and $I_{4}$ in which there was a difference of about $\mathrm{I} 4 \mathrm{~min} / \mathrm{kg}$ hay, the lactating cows eating most rapidly. More time was spent ruminating daily by the lactating than by the non-lactating cows, the longer time reflecting the greater amount of hay eaten by the lactating cows. When the time spent ruminating was expressed per $\mathrm{kg}$ hay eaten the lactating cows ruminated on average for $7.5 \mathrm{~min} / \mathrm{kg}$ hay less than their non-lactating twin-mates.

The interpretation of differences in the amount of time spent ruminating per $\mathrm{kg}$ hay between lactating and non-lactating cows is difficult because the lactating cows ate more hay than non-lactating cows and thus different ratios of hay to concentrates were eaten by the lactating and non-lactating cows. Recently it was observed that alterations in the ratio of hay to concentrates affect the amount of time spent ruminating per $\mathrm{kg}$ hay (Campling, unpublished). The mean daily number of periods of eating by the lactating and by the non-lactating cows was 12 . Also, the mean daily number of periods of rumination was 16 by the lactating cows and 16 by the nonlactating cows. There was, therefore, no effect of lactation on the number of periods of eating and rumination.

\section{DISCUSSION}

The value of monozygotic twin cattle for experiments on factors affecting the voluntary intake of food was mentioned by Reid (I957), who showed the similarity of the voluntary intake of fresh herbage by stall-fed twin cattle. The within-pair differences in intake of food dry matter were 0.30 and $0.35 \mathrm{~kg}$ for the two pairs examined. Earlier, Hancock (1952) reported estimates obtained by the chromic oxide technique of the intakes of twelve pairs of grazing monozygotic dairy cattle; the average within-pair difference was $0.4 \mathrm{~kg}$ dry matter and the range between pairs 
$2.8 \mathrm{~kg}$. The results of the very limited experiment now reported showed about the same degree of similarity in voluntary food intake within pairs of twin cattle as those described by Hancock (1952) and Reid (1957). The small difference (5\%) within pairs in the time spent chewing per $\mathrm{kg}$ hay during eating and ruminating was expected in view of the similarity within pairs of twins of dairy cows in the times spent grazing and ruminating (Hancock, 1950, 1954). In one trial with six pairs of cattle twins Hancock (1950) observed a mean within-pair difference of $8.5 \mathrm{~min}$ in grazing time, and in another trial with ten pairs of grazing twins the mean within-pair difference was $10.7 \mathrm{~min}$ (Hancock, 1954). That the same amount of food causes differences between pairs of twins in the daily amount of time spent ruminating was reported by Hancock (1952). Also, it is known from the observations of Kick, Gerlaugh, Schalk \& Silver (1937) and Freer et al. (1962) that among unrelated animals there is a tendency for each animal to have a characteristic number of periods of rumination each day; the results of Expt I suggest that this finding applies only to animals of different genotypes.

The effect of pregnancy in depressing the voluntary intake of hay observed in five of the six pairs of twins was similar to that observed in the cow by Hesselbarth (1954) and Mäkelä (1956); these authors thought the lowered intake was due to the space occupied by the gravid uterus. The small extent of the depression in intake of hay in the pregnant cows noticed in Expt 2 is in agreement with the statement by Hutton (1963). Also, in the Merino sheep Ferguson (1956) stated that voluntary food intake did not appear to be appreciably affected by pregnancy. However, in fat, twinbearing ewes a pronounced depression in voluntary food intake has often been observed in late pregnancy (Gordon \& Tribe, I951; Reid \& Hinks, I962; Owen \& Ingleton, I963). Reid \& Hinks (1962) suggested that, with the fat twin-bearing ewe, reduction in food intake was not simply a consequence of reduction in abdominal space due to the large volume occupied by twin foetuses or abdominal fat, but was probably related to metabolic changes that occur with pregnancy and fattening. In the study reported here none of the cows was unduly fat in late pregnancy and each cow gave birth to a single calf.

In this preliminary study, lactation was associated with a much greater change than pregnancy in the voluntary intake of hay; on average hay intake was $29 \%$ higher in the lactating cow than in the dry non-pregnant animal. The higher intake of food by the lactating cow agrees with the findings of Elliott et al. (196r) and Hutton (1963) in the cow and of Ferguson (1956), Cook, Mattox \& Harris (196r), Davies (1962), Owen \& Ingleton ( 1963 ) and Hadjipieris, Jones \& Holmes (I964) in the sheep. Close comparison on a quantitative basis between my results and those of Elliott et al. (I96I) and Hutton (1963) is not possible because of differences in diet and stage of lactation. Also, in the results presented by Hutton ( 1963 ) the changing quality of the freshly cut herbage was confounded with changes in the stage of lactation of the animals.

Further information is required of changes in voluntary food intake throughout the lactation and the dry period from stall-fed animals offered the same food ad lib. It was not possible because of the small scale of my study to examine in detail the relationship between voluntary food intake and milk yield, although various direct 
relationships have been reported in cattle and sheep (Cox, Foot, Hosking, Line \& Rowland, 1956; Davies, I962; Owen \& Ingleton, 1963; Hadjipieris et al. 1964).

Given a diet of concentrates ad lib., the lactating cow ate more food than the nonlactating cow (Table 9 ) but the increase $(8 \%$ ) was much smaller than with hay; the explanation of this result is not known. Aitken \& Preston (1964) reported that the voluntary food intake of cows given completely milled diets rose gradually from parturition to mid-lactation and that there was a marked fall in intake of food during the last 3 months of pregnancy.

That pregnancy did not cause any significant change in the amount of water drunk in five of the six pairs was not expected because Winchester \& Morris (1956) suggested that the water requirements of cattle increase appreciably during the the last 2 or 3 months of pregnancy. Although no reports were found of the effect of pregnancy on water intake in dairy cattle, Head (1953) observed that the daily intake of water by pregnant ewes increased from $1 \cdot 3 \mathrm{~kg}$ at the end of the $\mathrm{rst}$ month to $3 . \mathrm{Ig}$ at the ${ }_{5}^{\mathrm{th}}$ month of pregnancy.

The eating behaviour of the cows appeared to be only slightly affected by pregnancy and by lactation; in all but one of the pairs observed concentrates were eaten more slowly by the pregnant than by the non-pregnant cow and the lactating cow ate most rapidly of all. With hay there was again a tendency for the pregnant cows to have the slowest rate of eating ( $\mathrm{min} / \mathrm{kg}$ hay) and the lactating cows the fastest rate. Ruminating behaviour appeared to change little with pregnancy; the effect of lactation on rumination was confounded with changes in the ratio of hay to concentrates eaten which prevented the interpretation of the observed changes in time spent ruminating per $\mathrm{kg}$ hay. There is need for further work on the eating and ruminating behaviour of lactating and non-lactating twin cattle given similar amounts of the same food.

I am grateful to Mr V. W. Johnson and his colleagues for caring for the animals.

\section{REFERENCES}

Aitken, J. N. \& Preston, T. R. (I964). Anim. Prod. 6, 260.

Balch, C. C., Kelly, A. \& Heim, G. (195I). Br. F. Nutr. 5, 207.

Broster, W. H., Tuck, V. J. \& Balch, C. C. (1964). F. agric. Sci., Camb., 63, 5I.

Cook, C. W., Mattox, J. E. \& Harris, L. E. (1961). F. Anim. Sci. 20, 866.

Cox, C. P., Foot, A. S., Hosking, Z., Line, C. \& Rowland, S. J. (1956). F. Br. Grassld Soc. I1, Io7.

Davies, H. L. (1962). Proc. Aust. Soc. Anim. Prod. 4, 167.

Elliott, R. C., Fokkema, K. \& French, C. H. (196I). Rhodesia agric. F. 58, r24.

Ferguson, K. A. (1956). Proc. Aust. Soc. Anim. Prod. 1, 58.

Foot, A. S., Dodd, F. H. \& Soffe, D. W. (1960). Publs Eur. Ass. Anim. Prod. no. 9, p. 119.

Freer, M. \& Campling, R. C. (1965). Br. F. Nutr. 19, 195.

Freer, M., Campling, R. C. \& Balch, C. C. (1962). Br. F. Nutr. 16, 279.

Gordon, J. G. \&. Tribe, D. E. (195I). F. agric. Sci., Camb., 4I, I87.

Graves, R. R., Dawson, J. R., Kopland, D. V., Watt, A. L. \& Van Horn, A. G. (1938). Tech. Bull. U.S. Dep. Agric. no. 6ro.

Hadjipieris, D., Jones, J. G. W. \& Holmes, W. (1964). Anim. Prod. 6, 262.

Hancock, J. (r950). N.Z. Il Sci. Technol. A, 32, 22.

Hancock, J. (1952). N.Z. Fl Sci. Technol. A, 34, 131.

Hancock, J. (1954). F. agric. Sci., Camb., 44, 42I,

Head, M. J. (1953). F. agric. Sci., Camb., 43, 2 I4.

Hesselbarth, K. (I954). Arch. Tierernähr. 4, I 45. 
Hutton, J. B. (1963). Proc. N.Z. Soc. Anim. Prod. 23, 39.

Kick, C. H., Gerlaugh, P., Schalk, A. F. \& Silver, E. A. (1937). 7. agric. Res. 55, 587.

Legates, J. E., Murley, W. R. \& Waugh, R. G. (1956). F. Dairy Sci. 39, 937.

Mäkelä, A. (1956). Suom. MaatalSeur. Keskusl. Edust. Kok. Asiak. no. 85.

Owen, J. B. \& Ingleton, J. W. (I963). F. agric. Sci., Camb., 6r, 329.

Reid, C. S. W. (1957). N.Z. Fl Sci. Technol. A, 38, 825.

Reid, R. L. \& Hinks, N. T. (1962). Aust. F. agric. Res. 13, 1092.

Trimberger, G. W., Gray, H. G., Johnson, W. L., Wright, M. J., Vanvleck, L. D. \& Henderson, C. R. (1 963). Proc. Cornell Conf. Feed Manufacturers, p. 33.

Winchester, C. F. \& Morris, M. J. (1956). F. Anim. Sci. 15, 722. 